\title{
Perlindungan Hukum terhadap Korban Tindak Pidana Perdagangan Orang Dalam Perspektif Sistem Peradilan Pidana Indonesia dan Malaysia
}

\author{
Eko Budi $\mathbf{S}^{1^{*}}$, Wancik ${ }^{2}$ \\ ${ }^{1,2}$ Fakultas Hukum Universitas Batanghari \\ Jalan Slamet Riyadi Broni Kota Jambi Telp: (0741) 65351 \\ *Correspondence email: ekobudi1999@yahoo.co.id, wancikburhan@gmail.com
}

\begin{abstract}
Abstrak. Perlindungan hukum terhadap korban dalam sistem hukum pidana dan sistem peradilan di Indonesia dan Malaysia telah dilaksanakan namun belum mengakomodasi hak-hak korban secara keseluruhan dan pelaksanaannya belum sesuai dengan asasasas perlindungan hukum yang berlaku secara universal. Metode penelitian yang digunakan adalah penelitian hukum normatif, terdiri dari tipe penelitian terhadap perbandingan hukum dan sinkronisasi vertikal dan horizontal. Pendekatan yang digunakan adalah pendekatan undang-undang, kasus, perbandingan hukum dan konseptual. Tujuan dari penelitian ini adalah untuk menganalisis perlindungan hukum terhadap korban tindak pidana perdagangan orang dalam sistem hukum pidana di Indonesia dan Malaysia dan untuk menemukan konsep ideal perlindungan hukum terhadap korban tindak pidana perdagangan orang dalam perspektif sistem peradilan pidana Indonesia. Hasil dari penelitian tersebut adalah 1) Perlunya eksekutif dan legislatif merevisi Undang-Undang perlindungan saksi dan korban serta pemberantasan tindak pidana perdagangan orang yaitu dengan memasukkan hak-hak korban yang belum terakomodasi, 2) Agar Komponen Sistem Peradilan Pidana (Polri, Jaksa dan Hakim) mempunyai kesamaan visi dan mengutamakan profesionalisme serta keserasian antar komponen dalam memberikan perlindungan korban dengan berlandaskan asas-asas perlindungan korban dan 3) Perlunya dilakukan pembaharuan hukum dengan mengharmonisasi peraturan yang sudah ada dengan peraturan lainnya menjadi Konsep Perlindungan Hukum Integratif. Yaitu konsep perlindungan hukum terhadap korban perdagangan orang dengan menguatkan interaksi antara sistem hukum, meliputi sistem norma, sistem nilai dan sistem perilaku menjadi sistem perlindungan hukum integratif terhadap korban tindak pidana perdagangan orang dalam sistem peradilan pidana sebagai satu kesatuan yang utuh dan menyeluruh (Integral Komprehensif).
\end{abstract}

Kata kunci: Perlindungan korban; tindak pidana perdagangan orang; sistem peradilan pidana.

Abstract. Legal protection for victims in the criminal law system and the judicial system in Indonesia and Malaysia has been implemented but has not yet accommodated the rights of victims as a whole and its implementation has not been in accordance with the principles of universal legal protection. The research method used is normative legal research, consisting of the type of research on legal comparisons and vertical and horizontal synchronization. The approach used is the legal, case, comparative and conceptual approach. The purpose of this study is to analyze legal protection for victims of trafficking in the criminal law system in Indonesia and Malaysia and to find the ideal concept of legal protection for victims of trafficking in persons from the perspective of the Indonesian criminal justice system. The results of this research are 1) The need for the executive and legislative to revise the law on witness and victim protection and the eradication of the crime of trafficking in persons, namely by including the rights of victims that have not been accommodated, 2) so that the components of the criminal justice system (National Police Indonesia, Prosecutors and Judges) have the same vision and prioritize professionalism and harmony between components in providing protection for victims based on the principles of victim protection and 3) The need for legal reform by harmonizing existing regulations with other regulations into the Concept of Integrative Legal Protection. Namely the concept of legal protection for victims of trafficking in persons by strengthening the interaction between the legal system, including norms, value systems and behavior systems into an integrated legal protection system for victims of trafficking in persons in the criminal justice system as a whole and comprehensive (integral comprehensive).

Keywords: Victim protection; trafficking in person; criminal justice system.

\section{PENDAHULUAN}

Perlindungan hukum terhadap korban tindak pidana dilatarbelakangi dari pemikiran bahwa korban merupakan pihak yang dirugikan dalam hal terjadinya suatu kejahatan. Adanya ketidakseimbangan antara perlindungan korban kejahatan dengan pelaku kejahatan pada dasarnya merupakan salah satu pengingkaran, dari asas setiap warga negara sama kedudukannya dalam hukum, untuk itu perlunya substansi hukum dikaji ulang dalam melihat kepentingan yang lebih luas.

Dalam konsep perlindungan hukum terhadap korban kejahatan "terdapat beberapa asas hukum yang perlu diperhatian, asas-asas dimaksud adalah asas manfaat, asas keadilan, asas keseimbangan dan kepastian hukum." Selaras dengan teori perlindungan hukum, maka patut dipahami bahwa "upaya untuk mendapatkan perlindungan hukum yang diinginkan oleh manusia adalah ketertiban dan keteraturan antara nilai dasar dari hukum yakni adanya

${ }^{1}$ Dikdik M. Arief Mansur dan Elisatris Gultom, Urgensi Perlindungan Korban Kejahatan Antara Norma dan Realita, Raja Grafindo Persada, Jakarta, 2007, hal. 164. 
kepastian, kegunaan serta keadilan hukum, meskipun pada umumnya dalam praktek ketiga nilai tersebut bersitegang, namun harus diusahakan untuk ketiga nilai tersebut bersamaan."

Ketentuan mengenai perlindungan korban tindak pidana perdagangan orang di Indonesia diatur dalam UndangUndang Nomor 31 tahun 2014 tentang perubahan Undang- Undang Nomor 13 tahun 2006 tentang Perlindungan Saksi dan Korban (UU PSK), kecuali ditentukan lain dalam Undang-Undang Nomor 21 tahun 2007 tentang Pemberantasan Tindak Pidana Perdagangan Orang (UU PTPPO) sesuai dengan Pasal 43.

Bertambah maraknya masalah perdagangan orang di berbagai negara, termasuk Indonesia dan negara-negara yang sedang berkembang lainnya, telah menjadi perhatian Indonesia sebagai bangsa, masyarakat Internasional, dan anggota organisasi Internasional terutama Perserikatan Bangsa-Bangsa. "Karena perdagangan orang merupakan salah satu bentuk perlakuan terburuk dari pelanggaran harkat dan martabat manusia". ${ }^{4}$

Dalam tindak pidana perdagangan orang, korban diperdagangkan tidak hanya untuk tujuan pelacuran atau bentuk eksploitasi seksual lainnya, tetapi juga mencakup bentuk eksploitasi lain, misalnya kerja paksa atau pelayanan paksa, perbudakan, atau praktik serupa perbudakan itu. ${ }^{5}$ Pelaku tindak pidana perdagangan orang melakukan perekrutan, pengangkutan, pemindahan, penyembunyian, atau penerimaan orang untuk tujuan menjebak, menjerumuskan, atau memanfaatkan orang tersebut dalam praktik eksploitasi dengan segala bentuknya dengan ancaman kekerasan, penggunaan kekerasan, penculikan, pemalsuan, penipuan, penyalahgunaan kekuasaan atau posisi rentan, atau memberi bayaran atau manfaat sehingga memperoleh persetujuan dari orang yang memegang kendali atas korban. Perempuan dan anak adalah kelompok yang paling rentan menjadi korban tindak pidana perdagangan orang.

Ketentuan mengenai perlindungan korban tindak pidana perdagangan orang di Indonesia dilaksanakan berdasarkan Undang-Undang Nomor 31 tahun 2014 tentang perubahan Undang-Undang Nomor 13 tahun 2006 tentang Perlindungan Saksi dan Korban (selanjutnya disebut UUPSK), kecuali ditentukan lain dalam Undang-Undang Nomor 21 tahun 2007 tentang Pemberantasan Tindak Pidana Perdagangan Orang (selanjutnya disebut UU PTPPO) sesuai dengan Pasal 43. Dalam Undang-Undang tersebut mengatur tentang perlindungan korban sebagai aspek penting dalam penegakan hukum, yang dimaksudkan adalah dalam rangka untuk memberikan perlindungan dasar kepada korban. Selain itu undang-undang tersebut memberikan perhatian terhadap penderitaan korban sebagai akibat tindak pidana perdagangan orang, sebagai kompensasi dan restitusi bagi korban, mengatur juga rehabilitasi medis dan sosial, pemulangan serta reintegrasi yang harus dilakukan negara khususnya bagi korban yang mengalami penderitaan fisik, psikis dan sosial akibat tindak pidana perdagangan orang. ${ }^{6}$

Dalam penelitian ini, yang menjadi isu hukum antara lain, dalam UU Nomor 21 tahun 2007 tentang PTPPO terdapat beberapa norma-norma yang bertentangan dengan asas-asas perlindungan korban. Adanya kekaburan norma dalam ketentuan pidana undang-undang tersebut, salah satunya adalah dalam UU PTPPO belum secara spesifik mengandung asas keadilan dalam memberikan perlindungan hukum terhadap korban terutama anak-anak, karena ancaman pidana terhadap pelaku pidana perdagangan anak adalah sama dengan pelaku perdagangan orang dewasa.

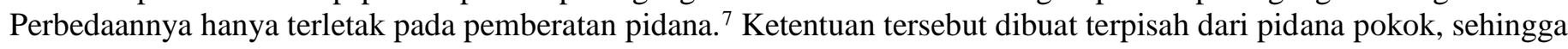
dapat dipersepsikan sebagai pidana tambahan yang bersifat fakultatif atau pilihan. Ketentuan pemberatan pidana yang terpisah dari pidana pokok perdagangan anak, sangat berpotensi merugikan karena dapat dipersepsi sebagai pidana tambahan yang bersifat fakultatif, yang boleh dijatuhkan boleh juga tidak. Manakala terjadi hal yang demikian, maka perbuatan pidana perdagangan anak dan perempuan, dianggap sama dengan perdagangan orang pada umumnya. Akibat logisnya adalah tujuan mendasar yang ingin dicapai dari diundangkannya UU PTPPO, yakni untuk melindungi anak dari kejahatan perdagangan orang pun belum memenuhi asas manfaat.

Dalam UU PTPPO juga tidak diatur secara limitatif mengenai kewenangan Jaksa dalam melakukan upaya hukum, baik dalam tingkat banding maupun kasasi terhadap putusan pengadilan dalam perkara TPPO. Akan tetapi, pasal 28 UU PTPPO menyatakan bahwa "Penyidikan, penuntutan, dan pemeriksaan di sidang pengadilan dalam perkara tindak pidana perdagangan orang, dilakukan berdasarkan Hukum Acara Pidana yang berlaku, kecuali ditentukan lain dalam Undang-Undang ini." Dengan demikian, KUHAP juga menjadi hukum acara pelaksanaan UU PTPPO. Pasal ini akan merugikan korban dalam memenuhi haknya dalam memperoleh hak restitusi, misalnya dalam hal penggabungan perkara pidana sebagaimana diatur dalam Pasal 98 sampai dengan 101 KUHAP. Dalam hal ini,

\footnotetext{
${ }^{2}$ Satijipto Raharjo, Ilmu Hukum, PT. Citra Aditya Bakti, Bandung, 2000, hal. 53.

${ }^{3}$ Marlina dan Azmiati Zuliah, Hak Restitusi Terhadap Korban Tindak Pidana Perdagangan Orang, Refika Aditama, Bandung, 2005, hal. 160 .

${ }^{4}$ Ibid., hal. 161 .

${ }^{5}$ Ibid.

${ }^{6}$ Ibid., hal. 162.

${ }^{7}$ Lihat Pasal 17, Undang-undang Nomor 21 Tahun 2007 tentang tentang Pemberantasan Tindak Pidana Perdagangan Orang. Pasal tersebut berbunyi, "Jika tindak pidana sebagaimana dimaksud dalam Pasal 2, Pasal 3, dan Pasal 4 dilakukan terhadap anak, maka ancaman pidananya ditambah $1 / 3$ (sepertiga)"
} 
tidak diajukan permintaan banding maka permintaan banding atas putusan ganti kerugian tidak diperkenankan. Dalam hal ini, korban akan dirugikan karena korban harus menerima putusan karena apabila terdakwa menyatakan banding maka secara otomatis perkara perdatanya mengikuti pemeriksaan banding. Apabila tidak, maka korban tidak diperkenankan untuk mengajukan banding atas gugatan ganti kerugian atau restitusi atas putusan yang dianggap tidak sesuai dengan beban kerugian yang dialami korban, baik materiil maupun immateriil. Sehingga dalam norma ini, jauh dari rasa keadilan.

Kemudian dalam hal pemberian restitusi dinyatakan dalam UU PTPPO, kata "dapat" dititipkan terlebih dahulu di pengadilan tempat perkara diputus. ${ }^{8}$ Artinya, bahwa dalam UU PTPPO terdapat peraturan yang kurang mendukung semangat undang-undang tersebut untuk memberikan perlindungan korban, yaitu ketentuan mengenai penitipan restitusi yang sifatnya sukarela. Tentang waktu penitipan uang restitusi dilakukan sejak tahap penyidikan, kata "dapat" pada pasal tersebut menimbulkan kekaburan norma, dan tidak tegas dalam memberikan perlindungan korban dalam hal pemberian restitusi. Sehingga dalam penitipan restitusi yang sifatnya sukarela, sangat bertentangan dengan asas kepastian hukum.

Dalam UU PTPPO juga tidak dijelaskan sejauhmana peran Jaksa dan bagaimana hubungan antara Jaksa dengan korban dan tidak ada ketegasan kewenangan Jaksa dalam hal mengajukan upaya hukum. Selain itu kewenangan Jaksa sebagai eksekutor putusan restitusi juga tidak diatur secara tegas, karena dalam Pasal 50 ayat (3) hanya memberi kewenangan Jaksa untuk menyita harta kekayaan pelaku setelah ada perintah dari Ketua Pengadilan bila restitusi tidak dibayar oleh pelaku. Hal tersebut mengandung tidak adanya kepastian dalam rangka perlindungan korban.

Selanjutnya dalam hal pidana kurungan pengganti, ${ }^{9}$ restitusi tidak dapat diganti dengan pidana kurungan karena bertentangan dengan semangat Undang-Undang Nomor 21 Tahun 2007 itu sendiri. Pidana pengganti seharusnya dihilangkan dan diganti dengan ketentuan bahwa restitusi "wajib" dibayar oleh pelaku dan akan menjadi hutang pelaku dan ahli waris jika ia belum mampu membayar, sehingga kapan saja pelaku/ahli warisnya punya kekayaan, Jaksa wajib melakukan penyitaan.

Sehingga pada tataran implementasi, masih banyak sikap penegak hukum dalam menerapkan aturan hukumnya seakan kurang peduli terhadap kerugian atau penderitaan yang dialami oleh korban padahal dalam Undang-Undang Nomor 21 Tahun 2007 telah diakomodir kepentingan korban mulai dari pada saat pelaporan sampai dengan putusan pengadilan. Dalam hal ini perlakuan yang baik terhadap korban harus diutamakan aparat penegak hukum dengan memberikan perhatian ketika seorang korban tindak pidana perdagangan orang melapor dengan mengikuti dan melaksanakan prinsip-prinsip dasar perlakuan terhadap korban.

Dalam penjatuhan sanksi pidana penjara pun belum dilakukan secara tepat dikarenakan hukuman yang diberikan terlalu ringan sehingga berpotensi menimbulkan pengulangan terhadap tindak pidana perdagangan orang karena tidak menimbulkan efek preventif (contohnya terhadap korban anak-anak, Undang-Undang Nomor 21 Tahun 2007 mengamanatkan adanya pemberatan apabila korban adalah anak-anak).

Perlindungan korban perdagangan orang sangatlah penting agar tidak terjadi perdagangan orang dengan korban yang sama. Perlindungan hukum ini diberikan agar korban merasa tenang dan aman tanpa rasa takut. Aparat hukum dan masyarakat seharusnya memperhatikan korban perdagangan orang sejak dari proses sebelum peradilan, jalannya persidangan, maupun setelah selesainya persidangan yang dikenal dengan sistem peradilan pidana.

Lain halnya perlindungan hukum terhadap korban perdagangan orang di Malaysia. Negara Malaysia merupakan salah satu negara tujuan/tempat terjadinya (locus delicti) bagi kejahatan perdagangan orang. Seseorang yang telah dinyatakan sebagai korban perdagangan orang oleh pejabat yang berwenang ditempatkan pada sebuah tempat perlindungan khusus dan dibedakan berdasarkan jenis kelamin dan usia. Untuk korban warga negara asli Malaysia diperbolehkan diberikan perlindungan penjagaan dalam keluarganya berdasarkan permohonan pihak keluarga. Sedangkan untuk korban warga negara asing, sementara menunggu penyelidikan dari pejabat berwenang diberikan kebebasan untuk tetap bekerja dibawah pengawasan pejabat tersebut serta bagi korban yang belum dibayarkan gajinya atau tertunggak pihak majikan harus membayarnya.

Melihat sistem peradilan yang diberlakukan di Malaysia terhadap perdagangan orang tersebut tidak jauh berbeda yang ada di Indonesia dalam hal penanganan suatu kejahatan yaitu melalui sistem peradilan, lembaga yang termasuk dalam sistem peradilan tersebut antara lain: Pegawai siasatan/penyidik Pegawai Polis, Penuntut (Peguam/Jaksa) dan Mahkamah (Pengadilan). Membandingkan hukum pidana di Indonesia dan Malaysia, merupakan hal menarik terkait penanganan kedua negara dalam perlindungan korban tindak pidana perdagangan orang. Dipilihnya Malaysia sebagai perbandingan karena beberapa hal, antara lain: Malaysia merupakan salah satu negara tujuan bagi tenaga kerja Indonesia ke luar negeri karena negara tersebut memberikan harapan gaji yang tinggi dan mampu menampung ribuan tenaga kerja serta merupakan locus delicty bagi adanya korban perdagangan orang yang

${ }^{8}$ Lihat Pasal 48 ayat (5), Undang-undang Nomor 21 Tahun 2007 tentang Pemberantasan Tindak Pidana Perdagangan Orang.

${ }^{9}$ Ibid., Pasal 50 ayat (4). 
berasal dari negara Indonesia. Ini ditandai, banyaknya tenaga kerja Indonesia di Malaysia yang setelah selesai masa kerjanya pulang ke Indonesia mengalami penderitaan baik fisik maupun psikis.

Sedangkan alasan lainnya adalah dari struktur budaya atau kultur Masyarakatnya, Indonesia dan Malaysia tidak jauh berbeda. Sedangkan dari segi dasar negara, Indonesia yang memiliki ideologi Pancasila, yang plural, heterogen dan memiliki letak geografis sebagai Negara kepulauan dan pernah di jajah oleh Belanda selama kurun waktu 350 tahun, dan kemudian mewarisi sistem hukumnya. Sedangkan Malaysia merupakan negara yang satu rumpun dengan Indonesia yang memiliki kesamaan budaya, masyarakatnya yang plural dan heterogen. Malaysia merupakan negara federasi bekas negara jajahan Inggris yang memiliki sistem hukum berbeda dengan Indonesia.

Belum sepenuhnya perlindungan terhadap korban kejahatan, merupakan indikasi belum adanya keadilan dan jaminan kesejahteraan dalam masyarakat. Ini berarti, "bahwa citra mengenai sesama manusia dalam masyarakat tersebut juga belum memuaskan dan perlu disempurnakan demi pembangunan manusia seutuhnya." ${ }^{10}$ Perlindungan terhadap para korban kejahatan pada hakekatnya juga merupakan suatu pola usaha kesejahteraan sosial yang pelaksanaannya harus semaksimal mungkin dilakukan oleh setiap masyarakat sesuai dengan kemampuannya masingmasing. ${ }^{11}$

Dalam perkembangannya korban bukanlah hanya sebagai objek suatu tindak pidana, akan tetapi harus dipahami bahwa korban sebagai subjek yang perlu mendapatkan perlindungan secara sosial dan hukum. Perlindungan korban kejahatan harus mendapat perhatian, dikarenakan sistem peradilan pidana terlalu memberikan perhatian pada permasalahan dan peran pelaku kejahatan (offender centered), terdapat potensi informasi dari korban untuk memperjelas dan melengkapi penafsiran tentang statistik kriminal melalui riset tentang korban dan harus dipahami bahwa korbanlah yang menggerakkan mekanisme sistem peradilan pidana dan semakin disadari bahwa selain korban kejahatan konvensional, tidak kurang pentingnya untuk memberikan perhatian kepada korban kejahatan nonkonvensional maupun korban penyalahgunaan kekuasaan. ${ }^{12}$

Berdasarkan uraian tersebut di atas, maka yang ingin dikaji dalam penulisan ini, adalah: Perlindungan hukum terhadap korban tindak pidana perdagangan orang dalam perspektif sistem peradilan pidana Indonesia dan Malaysia.

\section{METODE}

Metode penulisan yang penulis gunakan adalah menggunakan tipe penelitian normatif dengan perbandingan hukum, yaitu dengan memperbandingkan perlindungan hukum dalam suatu sistem hukum yang berbeda antara Indonesia dan Malaysia, antara lain mencakup pengaturan hukum (yuridis) tentang perlindungan hukum terhadap korban tindak pidana perdagangan orang dalam sistem peradilan pidana yang menjamin perlindungan hak-hak korban tindak pidana perdagangan orang.

Untuk menjawab permasalahan maka dilakukan pengumpulan bahan hukum melalui studi kepustakaan berupa bahan hukum primer, sekunder dan tersier, bahan-bahan tersebut kemudian diinventarisasi dan diidentifikasi, teknis analisis dilakukan secara interpretasi, yaitu bahan hukum diinterpretasikan dan dijabarkan dengan mendasarkan pada suatu norma dan pendekatan teori, sedangkan penarikan kesimpulan dilakukan dengan menggunakan metode penalaran secara deduktif.

\section{HASIL DAN PEMBAHASAN}

\section{Perlindungan hukum terhadap korban tindak pidana perdagangan orang dalam sistem hukum pidana di Indonesia dan Malaysia}

Pengaturan perlindungan korban dalam hukum pidana Indonesia diatur dalam beberapa peraturan perundangundangan, ${ }^{13}$ antara lain: KUHP, UU Nomor 31 tahun 2014 tentang Perlindungan saksi dan korban, UU Nomor 35 Tahun 2014 Tentang Perlindungan Anak dan UU Nomor 21 tahun 2007 tentang Pemberantasan Tindak Pidana Perdagangan Orang selanjutnya disebut UU PTPPO, sedangkan di Malaysia diatur dalam Akta 670 tentang Antipemerdagangan Orang dan Antipenyelundupan Migran 2007.

Perlindungan Korban dalam UU PTPPO, selain diwujudkan dalam bentuk dipidananya pelaku juga diwujudkan dalam bentuk pemenuhan hak-hak korban tindak pidana perdagangan orang sebagai berikut:

1. Hak kerahasiaan identitas korban dan keluarganya sampai derajat kedua (Psl 44);

2. Hak untuk mendapat perlindungan dari ancaman yang membahayakan diri, jiwa dan/atau hartanya (Psl 47);

3. Hak untuk mendapatkan restitusi (Psl 48);

4. Hak untuk memperoleh rehabilitasi kesehatan, rehabilitasi sosial, pemulangan, dan reintegrasi sosial dari

\footnotetext{
${ }^{10}$ Arif Gosita, Masalah Korban Kejahatan, Universitas Trisakti, Jakarta, 2014, hal. 17.

${ }^{11}$ Ibid., hal. 18.

${ }^{12}$ Mardjono Reksodiputro, HAM Dalam Sistem Peradilan Pidana Kumpulan Karangan, Buku ke II, LKUI, Jakarta, 2004,
} hal. 75 .

${ }^{13}$ Lilik Mulyadi, Kapita Selekta Hukum Pidana Kriminologi Dan Viktimologi, Djambatan, Jakarta, 2004, hal. 67. 
pemerintah (Ps1 51);

5. Korban yang berada di luar negeri berhak dilindungi dan dipulangkan ke Indonesia atas biaya negara (Psl 54).

Sedangkan hak-hak korban dalam Undang-Undang Nomor 31 Tahun 2014 tentang Perlindungan Saksi dan Korban, terdapat pada pasal 5 antara lain:

1. Memperoleh perlindungan atas keamanan pribadi, keluarga, \& harta bendanya, serta bebas dari ancaman yang berkenaan dgn kesaksian yg akan, sedang/telah diberikannya;

2. Memilih \& menentukan bentuk perlindungan \& dukungan keamanan;

3. Memberikan keterangan tanpa tekanan;

4. Mendapat penerjemah;

5. Bebas dari pertanyaan yg menjerat;

6. Mendapat informasi mengenai perkembangan kasus \& putusan pengadilan

7. Mendapat informasi dlm hal terpidana dibebaskan.

8. Dirahasiakan identitasnya \& mendapat identitas baru

9. Mendapat informasi dalam hal terpidana dibebaskan;

10.Mendapat tempat kediaman sementara \& kediaman baru

11.Memperoleh penggantian biaya transportasi sesuai dengan kebutuhan;

12.Mendapat nasihat hukum;

13. Memperoleh bantuan biaya hidup sementara sampai batas waktu perlindungan berakhir; dan/atau

14.Mendapat pendampingan

Perlindungan hukum terhadap korban tindak pidana perdagangan orang dalam sistem hukum Malaysia diatur dalam Akta 670 tentang Akta Antipemerdagangan orang dan Antipenyelundupan migran Malaysia 2007, yang ditindak lanjuti melalui Rencana Aksi Nasional Antipemerdagangan Orang dan Antipenyelundupan Migran. Kerajaan Malaysia telah menyediakan tempat perlindungan dan pemulihan untuk korban perdagangan orang. Tanggung jawab perlindungan tersebut diletakkan dibawah Kementerian Pembangunan Wanita, Keluarga dan Masyarakat (KPWKM). Ada empat (4) tempat perlindungan korban yang telah dioerasionalkan, antara lain di Lembah Klang, Melaka, Johor dan Sabah. Rumah perlindungan tersebut dilengkapi dengan fasilitas penginapan, makan minum, istirahat, ibadah dan diberikan bimbingan konseling.

Bagi korban perdagangan orang ditempatkan di pusat-pusat perlindungan seperti di Lembah Klang, Melaka, Johor dan Sabah. Pihak yang bertanggungjawab terhadap migran dan korban pemerdagangan orang juga dipisah, di mana untuk para migran diletakkan di bawah pengawalan Jabatan Imigresen Malaysia, sedangkan korban perdagangan orang ditempatkan di bawah tanggungjawab Kementerian Dalam Negeri dan Majlis Antipemerdagangan Orang dan Antipenyeludupan Migran (MAPOM). Tanggung jawab yang terpisah di antara Jabatan Imigresen dan Kementerian Dalam Negeri ini juga menimbulkan kesukaran untuk penyelidikan dan membedakan diantara status mereka sebagai pelaku/pesalah migran atau mangsa/korban pemerdagangan orang.

Perbedaan ini juga memberi kesan kepada jenis perlindungan yang akan diberikan kepada para korban. Para migran yang memasuki Malaysia tidak sah, akan ditempatkan di rumah tahanan Imigresen, salah satunya di Imegresan Lapangan Terbang Antarabangsa (KLIA) yang berfungsi sebagai tempat tahanan bagi para imigran sebelum dihantar pulang ke negara masing-masing. Adapun hak-hak korban perdagangan orang dalam Akta 670 antara lain:

1. Hak untuk tinggal sementara di rumah perlindungan (Seksyen 42);

2. Hak bantuan medis/pengobatan (Seksyen 45);

3. Hak untuk mendapatkan pengobatan di Rumah Sakit (Seksyen 47);

4. Hak untuk bekerja secara bebas (Seksyen 51A);

5. Hak mendapatkan penjagaan dari orang tua atau saudara (Seksyen 53);

6. Hak untuk dibebaskan dan pemulangan ke negara asal (Seksyen 54);

7. Hak untuk mendapatkan ganti rugi (Seksyen 66A);

8. Hak untuk mendapatkan gaji yang belum dibayarkan (Seksyen 66B).

Berikut ini adalah persamaan dan perbedaan tentang perlindungan hukum terhadap korban perdagangan orang dalam hukum pidana Indonesia dan Malaysia 
Eko Budi S dan Wancik, Perlindungan Hukum terhadap Korban Tindak Pidana Perdagangan Orang Dalam Perspektif Sistem Peradilan Pidana Indonesia dan Malaysia

\begin{tabular}{|c|c|c|c|}
\hline No & Jenis Perlindungan & UU PTPPO \& PSK Indonesia & AAPOM Malaysia \\
\hline 1 & 2 & 3 & 4 \\
\hline 1. & $\begin{array}{l}\text { Hak kerahasiaan identitas korban dan } \\
\text { keluarganya sampai derajat kedua. }\end{array}$ & $\begin{array}{l}\text { Diatur secara khusus dalam UU } \\
\text { PTPPO }\end{array}$ & Tidak diatur \\
\hline 2. & $\begin{array}{l}\text { Hak untuk mendapat perlindungan dari } \\
\text { ancaman yang membahayakan diri, jiwa dan } \\
\text { hartanya. }\end{array}$ & $\begin{array}{l}\text { Diberikan baik sebelum, selama } \\
\text { maupun sesudah proses pemeriksaan } \\
\text { perkara (Psl 47) }\end{array}$ & Tidak diatur secara tegas \\
\hline 3. & Hak untuk mendapatkan restitusi/ganti rugi. & Diatur secara khusus dalam Psl 48 & $\begin{array}{l}\text { Diatur secara khusus dalam } \\
\text { Sek } 66 \mathrm{~A}\end{array}$ \\
\hline 4. & $\begin{array}{l}\text { Hak untuk mendapatkan tempat kediaman } \\
\text { baru }\end{array}$ & $\begin{array}{l}\text { Diatur khusus dalam Psl } 5 \text { (1) huruf } \mathrm{j} \\
\text { UU PSK. }\end{array}$ & Tidak diatur \\
\hline 5 . & $\begin{array}{l}\text { Hak memperoleh penggantian biaya } \\
\text { transportasi sesuai dengan kebutuhan }\end{array}$ & $\begin{array}{l}\text { Diatur secara khusus dalam Psl } 5 \text { (1) } \\
\text { huruf } 1 \text { UU PSK. }\end{array}$ & Tidak diatur \\
\hline 6. & $\begin{array}{l}\text { Hak memperoleh bantuan biaya hidup } \\
\text { sementara }\end{array}$ & $\begin{array}{l}\text { Diatur secara khusus dalam Psl } 5 \text { (1) } \\
\text { huruf m UU PSK. }\end{array}$ & Tidak diatur \\
\hline 7. & $\begin{array}{l}\text { Hak untuk memperoleh rehabilitasi kesehatan, } \\
\text { kesehatan, rehabilitasi sosial, pemulangan, dan } \\
\text { reintegrasi sosial dari pemerintah. }\end{array}$ & $\begin{array}{l}\text { Diberikan kepada korban yang } \\
\text { mengalami penderitaan baik fisik } \\
\text { maupun psikis akibat tindak pidana } \\
\text { perdagangan orang (Psl 15) }\end{array}$ & $\begin{array}{l}\text { Diatur sebagai pengobatan } \\
\text { medis di RS terhadap } \\
\text { korban baik dewasa/ kanak- } \\
\text { kanak (Sek } 45 \text { dan } 47 \text { ) }\end{array}$ \\
\hline 8. & $\begin{array}{l}\text { Korban yang berada di luar negeri berhak } \\
\text { dilindungi dan dipulangkan ke negara asal. }\end{array}$ & $\begin{array}{l}\text { Diatur secara khusus dalam dalam } \\
\text { Ps1 } 54\end{array}$ & $\begin{array}{l}\text { Diatur secara khusus dalam } \\
\text { dalam Sek } 54\end{array}$ \\
\hline 9. & $\begin{array}{l}\text { Hak untuk tinggal sementara di rumah } \\
\text { perlindungan }\end{array}$ & Tidak diatur secara khusus & $\begin{array}{lr}\text { Diberikan } & \text { untuk } \\
\text { penyiasatan } & \text { sebelum } \\
\text { diserahkan ke } & \text { Majistret }\end{array}$ \\
\hline 10. & Hak untuk bekerja secara bebas & Tidak diatur secara khusus & $\begin{array}{l}\text { Diberikan kepada WN } \\
\text { asing yang bekerja di } \\
\text { Malaysia (Sek } 51 \mathrm{~A})\end{array}$ \\
\hline 11. & $\begin{array}{l}\text { Hak mendapatkan penjagaan dari orang tua } \\
\text { atau saudara }\end{array}$ & Tidak diatur secara khusus & $\begin{array}{l}\text { Diberikan kepada warga } \\
\text { negara atau penduduk tetap } \\
\text { Malaysia (Sek 53) }\end{array}$ \\
\hline 12. & $\begin{array}{l}\text { Hak untuk mendapatkan gaji yang belum } \\
\text { dibayarkan }\end{array}$ & Tidak diatur secara khusus & $\begin{array}{l}\text { Diatur secara khusus bagi } \\
\text { pekerja yg gajinya } \\
\text { tertunggak }(\mathrm{Sek} 66 \mathrm{~B})\end{array}$ \\
\hline
\end{tabular}

Jika disimpulkan tentang kelemahan dan keunggulannya maka perlindungan korban tindak pidana perdagangan orang dalam hukum pidana di Indonesia

Perlindungan Korban Dalam substansi hukum di Indonesia

Kelemahan Keunggulan

\footnotetext{
1. Belum mengakomodasi kepentingan korban secara keseluruhan.

2. Substansi mengenai definisi perdagangan dan hak anak, belum sepenuhnya merujuk pada ketentuan yang terdapat dalam Protokol Palermo. Perlindungan hukum terhadap korban terutama anak-anak, adalah sama dengan pelaku perdagangan orang dewasa. Ketentuan tersebut dibuat terpisah dari pidana pokok, pemberatan pidana yang terpisah dari pidana pokok, sangat berpotensi merugikan karena dapat dipersepsi sebagai pidana tambahan yang bersifat fakultatif, yang boleh dijatuhkan boleh juga tidak.

3. Tidak mengakui anak sebagai kasus khusus karena tidak ada pengecualian. Ketentuan ini tidak selaras dengan definisi dalam Protokol Palermo yang menyatakan bahwa anak adalah setiap orang yang berusia dibawah 18 tahun, definisi ini juga tidak dapat menjelaskan siapa yang menjadi korban perdagangan, apakah ibu yang mengandung atau anak yang dikandung, dan bagaimana bentuk eksploitasinya. Hal ini mengingat bahwa yang disebut perdagangan anak selain memenuhi salah satu elemen proses (rekrutmen, perpindahan, serah terima) juga harus terpenuhi bentuk eksploitasinya.
}

1. Persetujuan korban perdagangan orang tidak akan menghilangkan penuntutan tindak pidana perdagangan orang.

2. Perusahaan/korporasi yang terlibat akan dikenai sanksi hingga tiga kali lipat.

3. Terdapat sanksi tambahan berupa pencabutan izin usaha, perampasan kekayaan hasil tindak pidana, pemecatan pengurus dan pelarangan pengurus tersebut untuk mendirikan korporasi dalam usaha yang sama.

4. Dalam hal tatacara sistem peradilan, terutama korbannya adalah anak ada perlakuan tersendiri untuk tetap menjaga kondisi psikis anak tersebut agar tidak bertambah berat. 
4. Kewenangan Jaksa sebagai eksekutor putusan restitusi juga tidak diatur secara tegas.

5. Lemahnya daya paksa dan eksekusi pelaksanaan restitusi. Jika pelaku tidak mampu membayar restitusi, maka pelaku dapat dikenai pidana kurungan pengganti paling lama 1 (satu) tahun. Kata "dapat" pada substansinya menimbulkan kekaburan norma, dan tidak tegas dalam memberikan perlindungan korban dalam hal restitusi.

6. Adanya perbedaan dalam pembayaran ganti kerugian antara UUPTPPO/UUPSK dan KUHAP.

7. Dalam UU PSK belum mampu dilaksanakan dalam hal pemberian biaya transportasi kepada korban yang tidak mampu membiayai dirinya

8. untuk mendatangi lokasi, belum pernah diberikan meskipun dalam UU mengaturnya, pemberian biaya hidup sementara dan pemberian tempat tinggal baru.

9. Hukum acara belum memberikan batasan tentang pengembalian berkas perkara dari Penyidik kepada Penuntut.

Sedangkan kelemahan dan keunggulan perlindungan korban tindak pidana perdagangan orang dalam SPP di Indonesia, tergambar dalam tabel dibawah ini:

\section{Perlindungan Korban Dalam SPP}

\section{Kelemahan}

1. Putusan hakim kurang mencerminkan asas keadilan karena masih sering dalam putusannya tidak memuat restitusi.

2. Adanya perbedaan pendapat tentang restitusi antar komponen SPP.

3. Masih adanya ego sektoral antar komponen SPP dengan menonjolkan kewenangan masing-masing sehingga mengesampingkan kepentingan korban.

4. Adanya perbedaan pendapat tentang penerapan pasal.

5. KUHAP juga tidak mengatur mengenai berapa kali proses pengembalian berkas perkara tersangka dari penuntut umum kepada penyidik.

\section{Keunggulan}

1. Ada perlakuan tersendiri terhadap anak sebagai korban, untuk tetap menjaga kondisi psikis anak tersebut agar tidak bertambah berat.

2. Pada Tahap penyidikan, penuntutan, dan pemeriksaan di sidang pengadilan terhadap saksi dan/atau korban anak dilakukan dengan memperhatikan kepentingan yang terbaik bagi anak dengan tidak memakai toga atau pakaian dinas.

3. Komponen sistem peradilan pidana tersebut saling bekerjasama dan terikat pada satu tujuan yang sama.

4. Menjamin kepastian dalam tahap penyidikan

Adapun kelemahan dan keunggulan perlindungan korban dalam hukum pidana di Malaysia

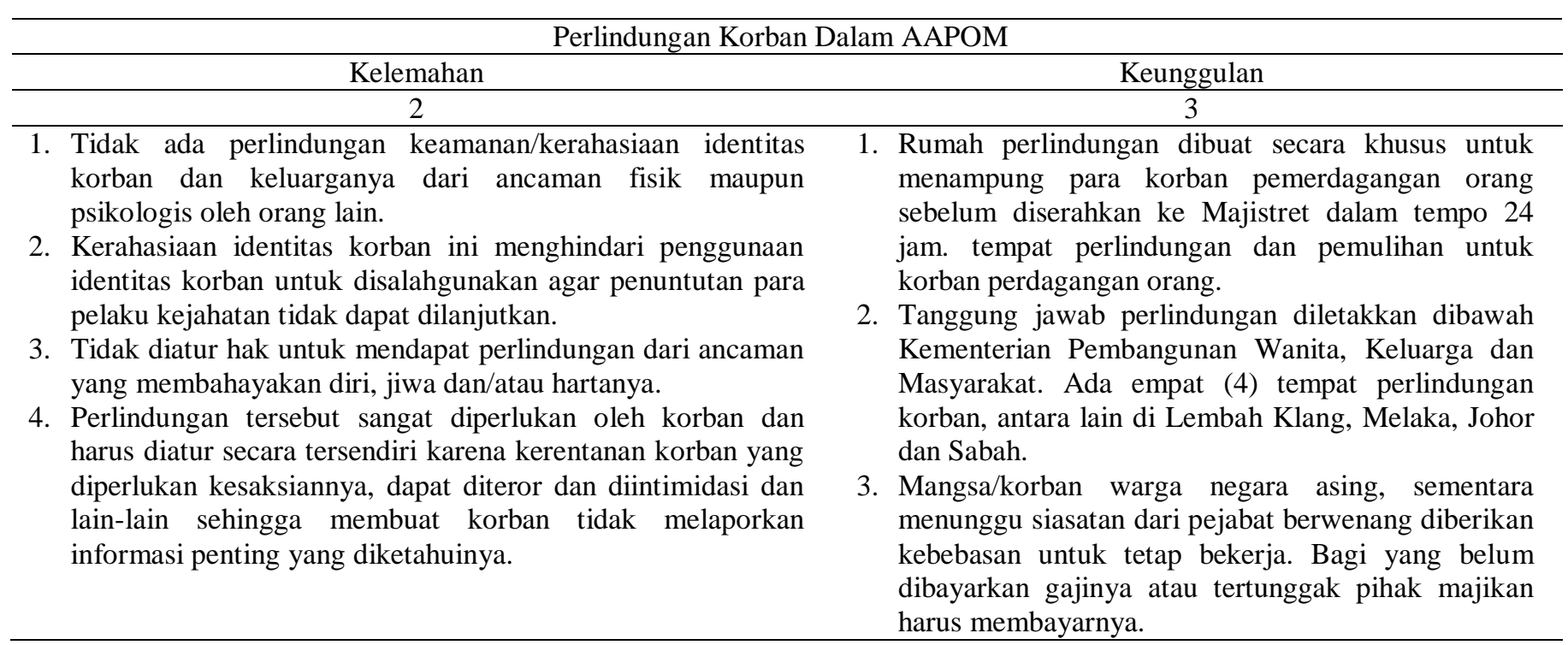

\section{Perlindungan Hukum terhadap Korban Perdagangan Orang dalam Sistem Peradilan Pidana di Indonesia dan Malaysia}

Perlindungan hukum terhadap korban perdagangan orang di Indonesia dalam Sistem Peradilan Pidana diatur dalam Pasal 28 UU No. 21 tahun 2007 tentang PTPPO yang merupakan pedoman bagi komponen Sistem Peradilan 
Pidana untuk melaksanakan penyidikan, penuntutan, dan pemeriksaan di sidang pengadilan yang dilakukan berdasarkan Hukum Acara Pidana yang berlaku, kecuali ditentukan lain dalam Undang - Undang tersebut.

Hukum Acara Pidana yang berlaku di Indonesia adalah KUHAP, yang didalamnya terdapat asas-asas Sistem Peradilan Pidana. Komponen sistem peradilan pidana di Indonesia terdiri dari Kepolisian, Kejaksaan, Pengadilan dan Lembaga Pemasyarakatan, termasuk Advokat. Proses dalam sistem peradilan pidana Indonesia diawali dalam tahap Penyidikan. Sebagai upaya dalam memberantas tindak pidana perdagangan orang melalui penegakan hukum pidana dengan sistem peradilan pidana (Integrated Criminal Justice System). Penyidikan mempunyai kedudukan dan peranan yang sangat penting dan strategis untuk menentukan berhasil tidaknya proses penegakan hukum pidana selanjutnya. Penyidikan tindak pidana perdagangan orang berdasarkan UUPTPPO dilakukan berdasarkan KUHAP sebagaimana yang dinyatakan dalam Pasal 28, sebagai berikut: Penyidikan, penuntutan, dan pemeriksaan di sidang pengadilan dalam perkara tindak pidana perdagangan orang, dilakukan berdasarkan Hukum Acara Pidana yang berlaku, kecuali ditentukan lain dalam undang-undang ini.

Pada awal tahapan penyidikan, korban perdagangan orang sudah mendapatkan perlindungan hukum, sebagaimana yang tercantum dalam UU PTPPO. Pasal 33, yang menyatakan:

1. Dalam penyidikan, penuntutan, dan pemeriksaan di sidang pengadilan, pelapor berhak dirahasiakan nama dan alamatnya atau hal-hal lain yang memberikan kemungkinan dapat diketahuinya identitas pelapor.

2. Dalam hal pelapor meminta dirahasiakan nama dan alamatnya atau hal-hal lain sebagaimana dimaksud pada ayat (1), kewajiban merahasiakan identitas tersebut diberitahukan kepada saksi dan orang lain yang bersangkutan dengan tindak pidana perdagangan orang sebelum pemeriksaan oleh pejabat yang berwenang yang melakukan pemeriksaan.

Ketentuan tersebut dilengkapai dengan sanksi pidana terhadap setiap orang yang memberitahu mengenai kerahasiaan identitas saksi atau korban dengan ancaman pidana minimal 3 (tiga) tahun dan maksimal 7 (tujuh) tahun dan denda minimal Rp. 120.000.000,00 (seratus dua puluh juta rupiah) dan paling banyak Rp. 280.000.000,00 (dua ratus delapan puluh juta rupiah). ${ }^{14}$ Selama dalam proses penyidikan, korban TPPO berhak didampingi oleh advokat dan/atau pendamping lainnya yang dibutuhkan, hal ini sesuai dengan Pasal 35. Sebagaimana yang dinyatakan dalam Pasal 36, yaitu: selama proses penyidikan, penuntutan, dan pemeriksaan di depan sidang pengadilan, korban berhak mendapatkan informasi tentang perkembangan kasus yang melibatkan dirinya. Sedangkan informasi tentang perkembangan kasus sebagaimana dimaksud pada ayat (1) dapat berupa pemberian salinan berita acara setiap tahap pemeriksaan.

Dalam hal korban beserta keluarganya mendapatkan ancaman yang membahayakan diri, jiwa, dan/atau hartanya, Kepolisian Negara Republik Indonesia wajib memberikan perlindungan, baik sebelum, selama, maupun sesudah proses pemeriksaan perkara, sesuai dengan Pasal 47 UUPTPPO. Dalam proses penyidikan, apabila korban mengalami kerugian baik materiil maupun nonmateriil, Polisi harus menyampaikan apakah korban mengehendaki ganti kerugian. Dalam rangka pengumpulan informasi perihal kerugian yang diderita korban dan kesediaan pelaku untuk memberikan ganti rugi ada di tahap penyidikan Polisi. Untuk itu, Polisi harus menyertakan atau melampirkannya dalam berita acara pemeriksaan (BAP), informasi yang berhubungan dengan kerugian korban.

Prosedur pengajuan restitusi bagi korban tindak pidana perdagangan orang atau ahli warisnya diatur dalam Pasal 48 ayat (1) yaitu "setiap korban tindak pidana perdagangan orang atau ahli warisnya berhak memperoleh restitusi". Dalam penjelasannya disebutkan bahwa mekanisme pengajuan restitusi dilaksanakan sejak korban melaporkan kasus yang dialaminya kepada Kepolisian Negara Republik Indonesia setempat dan ditangani oleh penyidik bersamaan dengan penanganan tindak pidana yang dilakukan. Ini artinya korban atau ahli warisnya dapat mengajukan tuntutan restitusi kepada pelaku sejak korban melaporkan kasus yang dialaminya dan harus dimuat dalam berkas perkara.

Pelaksanaan putusan restitusi yang telah mempunyai kekuatan hukum tetap, dilaksanakan dalam 14 (empat belas) hari terhitung sejak diberitahukannya putusan tersebut. ${ }^{15}$ Pelaksanaan pemberian restitusi dilaporkan kepada ketua pengadilan yang memutuskan perkara, disertai dengan tanda bukti pelaksanaan pemberian restitusi tersebut. Setelah ketua pengadilan menerima tanda bukti, ketua pengadilan mengumumkan pelaksanaan tersebut dipapan pengumuman pengadilan yang bersangkutan. Kemudian salinan tanda bukti pelaksanaan pemberian restitusi tersebut, disampaikan oleh pengadilan kepada korban atau ahli warisnya.

Penitipan uang restitusi dapat dilakukan seperti mekanisme konsinyasi dalam hukum perdata. Sejak tahap penyidikan, penyidik sudah menghitung besar nilai kerugian korban, selanjutnya melaporkan kepada Jaksa Penuntut Umum. Atas dasar laporan penyidik, penuntut umum mengajukan permintaan kepada Ketua Pengadilan Negeri (PN)

${ }^{14}$ Pasal 44 juncto Pasal 33 dan Pasal 24 Undang-Undang Nomor 21 tahun 2007 tentang Pemberantasan Tindak Pidana Perdagangan Orang.

${ }^{15}$ Ibid, Pasal 8 ayat 6. 
setempat melalui panitera untuk membuat "surat ketetapan" supaya pelaku menitipkan sejumlah uang sesuai dengan permintaan Jaksa selaku Penuntut Umum. Terhadap waktu penitipan dilakukan setelah ada putusan PN, adalah untuk memudahkan Hakim dalam penghitungan kerugian korban, walaupun hal ini sangatlah beresiko.

Dengan tidak adanya uang titipan sejak awal, dikhawatirkan pada saat eksekusi, harta pelaku sudah habis dan korban tidak mendapatkan apa-apa. Hal ini dapat dikarenakan harta kekayaan pelaku sudah dialihkan sebelum ada putusan Pengadilan Negeri (PN). Penjelasan pasal 48 ayat (5) UU PTPPO yang menyatakan bahwa penitipan restitusi dalam bentuk uang di pengadilan dilaksanakan sesuai dengan peraturan perundang-undangan. Ketentuan ini disamakan dengan proses penanganan perkara perdata dalam konsinyasi. Ini berarti, pelaksanaan Pasal 48 ayat (5) Undang-undang Nomor 21 Tahun 2007 tentang waktu penitipan uang restitusi, dilakukan sejak tahap penyidikan.

Keseluruhan proses penyidikan yang telah dilakukan oleh Penyidik Polri tersebut kemudian akan dilanjutkan oleh Kejaksaan dalam hal mempersiapkan penuntutan yang akan diajukan dalam sidang pengadilan dan selanjutnya penjatuhan vonis kepada terdakwa yang kesemuanya itu berlangsung dalam suatu sistem peradilan pidana dalam rangka penegakan hukum pidana. Peran Penuntut Umum dalam hal penuntutan terhadap tindak pidana perdagangan orang adalah Penuntut Umum dapat memberitahukan kepada korban tentang haknya untuk mengajukan ganti rugi (restitusi). Selanjutnya, Penuntut Umum menyampaikan jumlah kerugian yang diderita korban bersamaan dengan tuntutan.

Hal yang dapat dilakukan penuntut umum setelah penuntutan terhadap perkara tindak pidana perdagangan orang, seperti termuat dalam United Nation Trafficking Protocol yaitu:

1. Pelayanan dan perlindungan kepada korban, termasuk kedalamnya perlindungan sejauh memungkinkan, privasi dan identitas korban (Pasal 6 ayat 1)

2. Pemberian informasi yang relevan mengenai proses administratif dan pengadilan (Pasal 2 ayat 2).

3. Pelayanan atau pendampingan dalam rangka memungkinkan diungkap dan dimunculkannya pandangan dan kepentingan korban agar dapat turut dipertimbangkan oleh pengadilan pidana.

4. Perlindungan keselamatan fisik dari korban, kemungkinan mendapatkan ganti kerugian atas kerugian yang diderita.

Pemeriksaan di sidang pengadilan dalam perkara tindak pidana perdagangan orang dilakukan berdasarkan Hukum Acara Pidana yang berlaku, kecuali ditentukan lain dalam Undang-Undang PTPPO. Oleh karena itu lembaga peradilan sebagai lembaga penegak hukum dalam sistem peradilan pidana "criminal justice system" dan juga sebagai benteng terakhir dalam hal mencari keadilan menjadikan lembaga peradilan sebagai suatu tumpuan harapan dari para pencari keadilan yang selalu menghendaki peradilan yang sederhana, cepat dan biaya ringan. Keadilan yang hakiki merupakan sutau syarat yang utama untuk mempertahankan kelangsungan hidup suatu masyarakat, dalam hal hakim mempunyai suatu peranan penting dalam penegakan hukum pidana untuk tercapainya suatu keadilan yang diharapkan dan dicita-citakan. ${ }^{16}$

Dengan demikian dapat dikatakan bahwa pengadilan sebagai salah satu subsistem dalam Sistem Peradilan Pidana keberadaannya sangat penting, karena dengan tugas untuk mengadili setiap perkara pidana yang di sidangkan dan membuat suatu keputusan yang dapat menentukan nasib seseorang selain dianggap sebagai sarana untuk mengupayakan hukum, lembaga pengadilan pun merupakan tempat perlindungan hukum dan sekaligus sebagai tempat mencari keadilan hukum baik bagi warga negara maupun aparatur negara yang tersangkut dalam suatu sengketa hukum. Oleh sebab itu dapat dimaklumi keperluan akan adanya lembaga pengadilan yang baik, teratur serta memenuhi rasa keadilan masyarakat guna mewujudkan terselenggaranya negara hukum yang lebih baik. Sehingga peranan pengadilan tidak dapat disangsikan lagi, dengan lembaga pengadilan inilah segala yang menyangkut hak dan tanggungjawab yang terabaikan dapat diselesaikan. Lembaga ini memberikan tempat bahkan membantu kepada mereka yang merasa dirampas hak-haknya dan memaksa kepada pihak-pihak agar bertanggungjawab atas perbuatan yang dilakukan yang merugikan pihak lain, dengan begitu kejahatan pun dapat dikontrol, sesuai dengan tujuan dari Sitem Peradilan Pidana itu sendiri yaitu meminimalisir terjadi kejahatan di dalam kehidupan bermasyarakat. ${ }^{17}$

Selama proses pemeriksaan di sidang pengadilan, korban perdagangan orang berhak didampingi oleh advokat dan/atau pendamping lainnya yang dibutuhkan, sebagaimana yang dinyatakan dalam Pasal 35 pada Undang-Undang PTPPO. Advokat/Penasehat Hukum tersebut berperan sebagai pendamping dan konsultan dalam memberikan bantuan hukum kepada korban dalam menghadapi pemeriksaan di pengadilan. Pendamping lainnya ini antara lain adalah psikolog, psikiater, ahli kesehatan, rohaniawan dan anggota keluarga. Berbeda dengan ketentuan yang terdapat di dalam KUHAP, UU PTPPO dalam Pasal 37 Ayat (1) disebutkan bahwa saksi dan/atau korban berhak meminta kepada hakim ketua sidang untuk memberikan keterangan di depan sidang pengadilan tanpa kehadiran terdakwa.

${ }^{169}$ Yesmil Anwar dan Adang, Sistem Peradilan Pidana (Konsep Komponen, Dan Pelaksanaannnya Dalam Penegakan Hukum Di Indonesia), Widya Padjadjaran, Bandung, 2009, hal. 201.

${ }^{17}$ Rusli Muhammad, Kemandirian Pengadilan Indonesia, FH UII Press, Yogyakarta, 2010, hal. 13. 
Sebagaimana dinyatakan dalam Pasal 37, bahwa saksi dan/atau korban berhak meminta kepada hakim ketua sidang untuk memberikan keterangan di depan sidang pengadilan tanpa kehadiran terdakwa. Dalam hal saksi dan/atau korban akan memberikan keterangan tanpa kehadiran terdakwa, hakim ketua sidang memerintahkan terdakwa untuk keluar ruang sidang. Pemeriksaan terdakwa sebagaimana dimaksud pada ayat (2) dapat dilanjutkan setelah kepada terdakwa diberitahukan semua keterangan yang diberikan saksi dan/atau korban pada waktu terdakwa berada di luar ruang sidang pengadilan.

UU PTPPO memberikan perhatian dan pengaturan secara khusus terhadap anak sebagai korban tindak pidana perdagangan orang. Pasal 1 angka 5, menyatakan anak adalah seseorang yang belum berusia 18 (delapan belas) tahun, termasuk anak yang masih dalam kandungan, sehingga anak yang masih dalam kandungan pun sudah dapat dimungkinkan menjadi korban TPPO. Dengan memperhatikan asas kepentingan terbaik bagi anak, antara lain dengan pemeriksaan di persidangan oleh Hakim dan Jaksa tidak memakai toga atau baju dinas persidangan, sidang dilakukan secara tertutup, korban anak wajib didampingi oleh orang tua, wali, orang tua asuh, advokat atau pendamping lainnya. Pemeriksaan korban anak dilakukan tanpa kehadiran terdakwa dan atas persetujuan hakim, pemeriksaan terhadap korban anak dapat dilakukan di luar sidang pengadilan dengan mengunakan alat perekam dan dilakukan di hadapan pejabat yang berwenang (penyidik atau penuntut umum). ${ }^{18}$

Dalam hal, restitusi belum dibayarkan kepada pihak korban sampai melampaui batas waktu sebagaimana dimaksud dalam Pasal 48 ayat (6), maka pengadilan sesuai dengan Pasal 50 memberikan surat peringatan secara tertulis kepada pemberi restitusi, untuk segera memenuhi kewajiban memberikan restitusi kepada korban atau ahli warisnya. Dalam hal surat peringatan sebagaimana dimaksud pada ayat (2) tidak dilaksanakan dalam waktu 14 (empat belas) hari, pengadilan memerintahkan Penuntut Umum untuk menyita harta kekayaan terpidana dan melelang harta tersebut untuk pembayaran restitusi. Jika pelaku tidak mampu membayar restitusi, maka pelaku dikenai pidana kurungan pengganti paling lama 1 (satu) tahun.

Sementara itu, Malaysia sebagai negara bekas jajahan kolonial Inggris, hukum positif yang berlaku di Malaysia banyak mengadopsi hukum yang berlaku di Inggris atau negara- negara jajahan Inggris, seperti India dan Hongkong. Di dalam sistem peradilan pidana di Malaysia digunakan sistem "doktrin kehakiman yang mengikat yang diambil dari sistem hukum Inggris." 19 Sistem kekuasaan kehakiman di Malaysia juga menganut sistem hukum Inggris, meliputi: Pemerintah Persekutuan Malaysia (Pusat) dan Kerajaan Negeri (Negara Bagian) ke dalam Mahkamah Sivil (Peradilan Umum) dan Mahkamah Syariah (Peradilan Agama). ${ }^{20}$ Sistem hukum di Malaysia didasarkan pada seperangkat hukum tertulis dan tidak tertulis. Di antara yang tertulis adalah Konstitusi Federal bersama-sama dengan konstitusi dari 13 negara yang terdiri dari Federasi, legislasi diberlakukan oleh Parlemen dan Majelis Negara, dan didelegasikan untuk dibuat oleh Badan-badan di bawah kekuasaan yang diberikan pada mereka oleh Parlemen atau Majelis Negara. Hukum tak tertulis terdiri dari prinsip-prinsip hukum Inggris umum disesuaikan dengan keadaan setempat, kasus hukum dan hukum adat setempat, hukum Islam juga merupakan sumber penting dari hukum yang berlaku hanya untuk penduduk Muslim dan dikelola oleh sistem yang terpisah dari pengadilan.

Komponen sistem peradilan pidana di Malaysia terdiri dari Polis Diraja Malaysia, Penuntut Umum (Peguam Negara) dan Hakim. Berdasarkan Akta 670 tentang Antipemerdagangan Orang dan Antipenyelundupan Migran maka dibentuklah Majelis Antipemerdagangan Orang dan Antipenyeludupan Migran (MAPO). Majelis ini dipimpim oleh Ketua Setiausaha Kementerian Dalam Negeri dan beranggotakan dari Kementerian dan Agensi terkait serta Lembaga bukan Kerajaan. Selanjutnya ada lima (5) Jawatankuasa (Aparat Penegak Hukum) yang diberi wewenang untuk melaksanakan Akta tersebut, antara lain: Polis Diraja Malaysia, Jabatan Imigresen Malaysia, Kastam Diraja Malaysia, Agensi Penguatkuasaan Maritim Malaysia; dan Jabatan Tenaga Kerja. ${ }^{21}$

Dalam proses sistem peradilan pidana di Malaysia pada tahap penyelidikan dan penyidikan dalam tindak pidana perdagangan orang terdiri dari: Pegawai Polisi, Pegawai Imigresen, Pegawai Kastam, Pegawai Agensi Penguatkuasaan Maritim Malaysia APMM) dan Pegawai Tenaga Kerja berdasarkan Akta 670/AAPOM. ${ }^{22}$ Dalam Seksyen 29, pegawaipegawai tersebut diberi kuasa untuk menangkap pelaku perdagangan orang. Bagi seseorang pegawai penegak hukum yang telah melakukan penangkapan di bawah subseksyen (1), haruslah segera membawa orang yang ditangkap itu ke Kantor Polisi terdekat dan setelah itu, orang itu harus diperlakukan sesuai undang-undang yang berkaitan dengan Tatacara Jenayah (KUHAP) yang berlaku.

Seorang pegawai penegak hukum diperbolehkan atas kehendaknya apabila orang yang dijumpai atau diselamatkan tersebut adalah orang yang diperdagangkan, maka harus membawa orang itu ke dalam perlindungan sementara dan membawa orang itu ke hadapan Majistret dalam waktu 24 (dua puluh empat) jam, tidak termasuk

\footnotetext{
${ }^{18}$ Pasal 38, 39 dan 40 Undang-Undang Nomor 21 Tahun 2007 tentang Pemberantasan Tindak Pidana Perdagangan Orang.

${ }^{19}$ Mohammad Shariff dan Aisyah, Undang-Undang Jenayah di Malaysia, Tanpa Tahun.

${ }^{20}$ Rusliansyah, file:///F:/Traficking/Mengenal Sistem Kekuasaan Kehakiman di Malaysia.pdf, diunduh tanggal 1 Juli 2020.

${ }^{2114}$ Seksyen 27, Akta 670 tentang Antipemerdagangan Orang dan Antipenyeludupan Migran 2007.

${ }^{22}$ Ibid, Seksyen 28.
} 
waktu yang diperlukan untuk perjalanan ke Mahkamah Majistret, untuk memperoleh perintah perlindungan interim (Interim Protection Order/IPO). ${ }^{23}$ Selanjutnya Majistret akan membuatkan perintah perlindungan interim bagi orang yang ditempatkan di tempat perlindungan selama 14 (empat belas) hari untuk menjalankan penyelidikan dan penyidikan di bawah Seksyen 51. ${ }^{24}$ Setelah penyidik memperoleh perintah yang dikeluarkan di bawah subseksyen (2), menyerahkan orang yang diperdagangkan itu kepada pegawai pelindung untuk menempatkan orang yang diperdagangkan itu di tempat perlindungan yang dinyatakan dalam perintah tersebut.

Apabila selesai dilakukan penyidikan, Pegawai Penegak Hukum dan Pegawai Pelindung secara bersama-sama membuat laporan dan melaporkan bersama-sama ke hadapan Mahkamah Majistret untuk menjelaskan kepada Majistret bahawa orang itu benar- benar adalah orang yang diperdagangkan di bawah akta ini. Jika Majistret yakin bahawa orang yang dibawa ke hadapannya adalah orang yang diperdagangkan dan memerlukan jagaan dan perlindungan, maka Majistret akan membuat perintah perlindungan. ${ }^{25}$

Dalam hal orang yang diperdagangkan ialah seorang warganegara tetap Malaysia, Majistret memerintahkan orang yang diperdagangkan itu ditempatkan di tempat perlindungan selama waktu tidak melebihi dua tahun dari saat perintah tersebut dikeluarkan, jika orang yang diperdagangkan ialah seorang warganegara asing, memerintahkan orang yang diperdagangkan itu untuk ditempatkan di tempat perlindungan selama tempoh tidak melebihi tiga bulan dari saat perintah itu, dan selepas itu menyerahkannya kepada Pegawai Imigresen untuk dilakukan tindakan sesuai Akta Imigresen 1959/63.

Tetapi jika bukan orang yang diperdagangkan adalah seorang warganegara tetap malaysia, Majistret memerintahkan orang itu untuk dilepaskan atau jika orang itu warganegara asing, Majistret memerintahkan orang itu diserahkan kepada Pegawai Imigrasi untuk tindakan yang perlu sesuai Akta Imigresen 1959/63. Disamping itu Majistret boleh pada suatu saat, atas permohonan Pegawai Penegak Hukum atau Pegawai Pelindung, dapat melanjutkan atau membatalkan perintah perlindungan yang dibuat di bawah seksyen tersebut. Dalam hal orang yang diperdagangkan itu ialah seorang warganegara asing, perintah perlindungan boleh diberikan hanya untuk menyelesaikan penyidikan di bawah Seksyen 52 atau untuk situasi keadaan yang luar biasa sebagaimana yang ditentukan oleh Majistret tersebut.

Pada tahap penuntutan dimulai terhadap orang-orang yang diduga di bawah akta tersebut, penuntutan dilaksanakan dengan menghadapkan orang yang diperdagangkan itu ke hadapan Mahkamah Sesyen, yang penuntutan perkaranya telah dimulai untuk diambil keterangan dan bersumpah bagi orang yang diperdagangkan itu. Hakim Mahkamah Sesyen diperbolehkan berdasarkan permohonan, untuk mengeluarkan perintah yang ditujukan kepada orang yang bertanggungjawab atas tempat perlindungan di mana orang yang diperdagangkan itu ditempatkan, menghendakinya untuk mengemukakan orang yang diperdagangkan itu pada masa dan di tempat yang dinyatakan dalam dakwaan atau perintah itu.

Disamping itu Hakim Mahkamah Sesyen harus mengambil keterangan orang yang diperdagangkan itu dan menyelesaikan dalam masa 7 (tujuh) hari dari waktu penghadapan orang yang diperdagangkan itu ke hadapannya. Pada saat pengambilan keterangan orang yang diperdagangkan itu, dia harus diperiksa berdasarkan Akta Keterangan 1950. Hakim Mahkamah Sesyen harus membuat keterangan dalam bentuk tertulis dan pada akhir tulisan itu dan harus di tandatangani keterangan itu. Jika dalam keterangan tersebut lain/berlawanan, keterangan yang diambil di bawah seksyen ini harus diterima sebagai keterangan dalam persidangan di bawah akta ini dan perlakuan keterangan itu hendaklah sama sebagaimana seorang saksi yang hadir dan memberi keterangan dalam persidangan.

Adapun persamaan dan perbedaan tentang perlindungan hukum terhadap korban perdagangan orang dalam SPP dapat di gambarkan dalam tabel berikut ini:

\begin{tabular}{ccll}
\hline NO & \multicolumn{1}{c}{ JENIS } & \multicolumn{1}{c}{ INDONESIA } & \multicolumn{1}{c}{ MALAYSIA } \\
\hline 1 & \multicolumn{1}{c}{2} & \multicolumn{1}{c}{3} & \multicolumn{1}{c}{4} \\
\hline 1. & Komponen & $\begin{array}{l}\text { Polisi, Jaksa, Hakim, Advokat (KUHAP) dan } \\
\text { Satgas Anti Trafficking (Perpres) } \\
\text { Penyidikan, Penuntutan, Pemeriksaan, } \\
\text { Pengadilan }\end{array}$ & $\begin{array}{l}\text { Polis, Kastam, Imigresen, APPM, Tenaga } \\
\text { Kerja, Penuntut, Hakim } \\
\text { Penyidikan, Penuntutan, Pemeriksaan } \\
\text { Pengadilan }\end{array}$ \\
\hline
\end{tabular}

Kelemahan dan Keunggulan Perlindungan Korban Dalam SPP di Malaysia

\footnotetext{
${ }^{23}$ Ibid, Seksyen 44 (1).

${ }^{24}$ Ibid., Seksyen 44 (2).

${ }^{25}$ Ibid., Seksyen 51 (3).
} 
Eko Budi S dan Wancik, Perlindungan Hukum terhadap Korban Tindak Pidana Perdagangan Orang Dalam Perspektif Sistem

\begin{tabular}{|c|c|}
\hline \multicolumn{2}{|c|}{ Perlindungan Korban Dalam SPP } \\
\hline Kelemahan & Keunggulan \\
\hline 1 & 2 \\
\hline $\begin{array}{l}\text { 1. Adanya disparitas penjatuhan pidana kepada para pelaku. } \\
\text { 2. Masih terjadi adanya persekongkolan antara sindikat dan } \\
\text { Pegawai Penegak Hukum. }\end{array}$ & $\begin{array}{l}\text { 1. Semua penegak hukum yang ada dalam Akta } 670 \\
\text { diberikan kewenangan penyidikan } \\
\text { 2. Pemberian perlindungan, dilaksanakan secara cepat } \\
\text { atas perintah Majistret. }\end{array}$ \\
\hline $\begin{array}{l}\text { 3. Sebagian besar korban dan/saksi takut melaporkan kejadian } \\
\text { perdagangan orang karena mereka diancam para agen } \\
\text { sindikat. } \\
\text { 4. Penanganan tindak pidana perdagangan orang terkesan } \\
\text { ditutup-tutupi oleh para penegak hukum. }\end{array}$ & $\begin{array}{l}\text { 3. Pelaksanaan perlindungan lebih terkoordinasi dan } \\
\text { bersama-sama antara SPP dan MAPO } \\
\text { 4. Tempat perlindungan yang representative dengan } \\
\text { memperhatikan standar bagi pemenuhan HAM. }\end{array}$ \\
\hline
\end{tabular}

\section{Konsep ideal perlindungan hukum terhadap korban tindak pidana perdagangan orang dalam perspektif sistem peradilan Pidana di Indonesia}

Berdasarkan argumentasi-argumentasi tersebut diatas, dapat ditarik benang merah bahwa perlindungan hukum terhadap korban perdagangan orang, dapat dimaknai sebagai upaya mengembalikan hak-hak korban hingga terpulihkan seperti sediakala sebagaimana sebelum kejahatan menimpanya. Negara dalam konteks ini harus bersikap progresif untuk menuntut pelaku bertanggungjawab atas pemulihan korban di satu sisi. Sementara itu di sisi lain negara bertanggungjawab atas kelalaiannya menjaga warganya dari akibat kejahatan (perspektif korban) dan juga negara bertanggungjawab atas kelengahannya mengantisipasi terjadinya peristiwa jahat (perspektif situasi dan kondisi serta motivasi Pelaku berani melakukan perbuatan jahatnya). Pentingnya korban memperoleh perlindungan dan pemulihan sebagai upaya menyeimbangkan kondisi korban yang mengalami gangguan, dengan tepat perlindungan korban menurut hukum positif yang berlaku. Dalam hukum pidana positif berlaku saat ini, perlindungan korban lebih banyak merupakan "perlindungan abstrak" atau perlindungan tidak langsung". ${ }^{26}$

Ruang lingkup pembaharuan perlindungan hukum terhadap korban tindak pidana perdagangan orang dalam hukum pidana di Indonesia, dapat dilihat berikut ini:

\begin{tabular}{cc}
\hline NO & SUBSTANSI UU \\
\hline 1 & \multicolumn{1}{c}{2} \\
\hline 1. & UU PTPPO belum mengakomodasi kepentingan korban \\
& $\begin{array}{l}\text { secara keseluruhan (Bab V tentang Perlindungan Saksi } \\
\text { dan Korban Perdagangan Orang) }\end{array}$
\end{tabular}

2. Definisi anak dan kualifikasi perdagangan anak, ketentuan ini tidak selaras dengan definisi dalam Protokol Palermo. Terutama tentang elemen proses (rekrutmen, perpindahan, serah terima) juga harus terpenuhi bentuk eksploitasinya.

Masuknya "cara" sebagai unsur tindak pidana perdagangan anak menyebabkan beban pembuktian yang lebih berat bagi pelaku. Jika cara yang digunakan tidak tercantum dalam UU, pelaku bisa lepas dari jeratan hukum.

3. Subjek Pidana belum menyentuh pada aparatur pemerintah terendah yang berhubungan langsung dengan calon korban (Penjelasan Pasal 8 (1))

Dalam penjelasan perlu dijelaskan tentang siapa saja yang menjadi penyelenggara pemerintah mulai dari terendah. 
4. Pada Pasal 48 ayat (5) disebutkan bahwa restitusi dapat dititipkan terlebih dahulu di pengadilan tempat perkara diputus. Kata "dapat" tersebut menimbulkan kekaburan norma, dan tidak tegas dalam memberikan perlindungan korban dalam hal restitusi.

5. Kewenangan Jaksa sebagai eksekutor putusan restitusi tidak diatur secara tegas, karena dalam Pasal 50 ayat (3) hanya memberi kewenangan Jaksa untuk menyita harta kekayaan pelaku setelah ada perintah dari Ketua Pengadilan bila restitusi tidak dibayar oleh pelaku.

6. Restitusi tidak dapat diganti dengan pidana kurungan (Pasal 50 (3)).
Kata "dapat" harus diubah menjadi "wajib", karena kata "wajib" mengandung ketegasan bahwa perintah undangundang harus diikuti oleh siapa pun tanpa terkecuali. Dengan kata lain, pelaku TPPO wajib menitipkan uang restitusi, kalau tidak diikuti dengan upaya paksa maka ketentuan itu akan sia-sia. Sebab apabila pelaku tidak mau menitipkan uang restitusi ke pengadilan juga tidak ada sanksi yang akan diberikan kepada pelaku. Ini berarti, salah satu unsur sistem hukum, yaitu dapat diaplikasikannya peraturan tidak dapat terwujud. Tidak berfungsinya salah satu unsur maka sistem hukum tidak akan berjalan dengan efektif.

Perlunya dipertegas ketentuan tersebut tentang kewenangan Jaksa sebagai eksekutor putusan restitusi sehingga jelas tugas dan wewenang Jaksa dalam melaksanakan eksekusi.

Pidana pengganti seharusnya dihilangkan dan diganti dengan ketentuan bahwa restitusi wajib dibayar oleh pelaku dan akan menjadi hutang pelaku dan ahli waris jika ia belum mampu membayar, sehingga kapan saja pelaku/ahli warisnya punya kekayaan, Jaksa wajib melakukan penyitaan.

Alternatif lain bila hal itu sulit dilakukan ialah batas maksimalnya pidana pengganti disesuaikan dengan kerugian korban, karena bila batas maksimalnya hanya 1 (satu) tahun sedangkan nilai kerugian korban sangat besar, maka pelaku akan lebih memilih pidana pengganti dan ini sangat bertentangan dengan rasa keadilan masyarakat. Indonesia

Sedangkan pembaharuan perlindungan hukum terhadap korban tindak pidana perdagangan orang dalam SPP di

\begin{tabular}{|c|c|c|}
\hline $\mathrm{NO}$ & SPP SAAT INI & USULAN KONSEP IDEAL \\
\hline 1 & 2 & 3 \\
\hline 1. & $\begin{array}{l}\text { Putusan Hakim kurang mencerminkan asas keadilan } \\
\text { karena masih sering dalam putusannya tidak memuat } \\
\text { restitusi. }\end{array}$ & $\begin{array}{l}\text { Harusnya Hakim berpedoman dengan UU yang berlaku dalam } \\
\text { memberikan putusan dan berdasarkan keyakinannya dalam ikut } \\
\text { mewujudkan perlindungan korban }\end{array}$ \\
\hline 2. & $\begin{array}{l}\text { Perbedaan pendapat tentang restitusi antar komponen } \\
\text { SPP. }\end{array}$ & $\begin{array}{l}\text { Komponen SPP harus lebih memahami tentang pemberian } \\
\text { restitusi sebagai salah satu hak korban yang harus dipenuhi }\end{array}$ \\
\hline 3. & $\begin{array}{l}\text { Ego sektoral antar komponen SPP dengan } \\
\text { menonjolkan kewenangan masing-masing sehingga } \\
\text { mengesampingkan kepentingan korban. }\end{array}$ & $\begin{array}{l}\text { Komponen SPP harus mempunyai kesamaan visi dalam rangka } \\
\text { memberikan perlindungan korban dengan mengedepankan } \\
\text { asas-asas perlindungan korban. }\end{array}$ \\
\hline 4. & Adanya perbedaan pendapat tentang penerapan pasal. & Perlunya ditingkatkan kembali koordinasi antar komponen SPP \\
\hline 5. & $\begin{array}{l}\text { KUHAP juga tidak mengatur mengenai berapa kali } \\
\text { proses pengembalian berkas perkara tersangka dari } \\
\text { penuntut umum kepada penyidik. }\end{array}$ & $\begin{array}{l}\text { Perlu dikoordinasikan antara Penyidik dan Penuntut agar } \\
\text { berkas penyidikan cepat selesai dengan tidak } \\
\text { mengenyampingkan profesionalisme dan keserasian antar } \\
\text { komponen SPP. }\end{array}$ \\
\hline 6. & $\begin{array}{l}\text { Putusan hakim belum mengakomodir hak korban } \\
\text { dalam UU PSK }\end{array}$ & $\begin{array}{l}\text { Perlu diakomodir hak-hak korban dalam UU PSK seperti } \\
\text { pemberian tempat tinggal, biaya transportasi dan biaya hidup } \\
\text { sementara. }\end{array}$ \\
\hline
\end{tabular}

Karakteristik korban perdagangan orang adalah seseorang yang telah mengalami penderitaan fisik dan atau psikis yang diakibatkan adanya tindakan kekerasan, baik kekerasan fisik, kekerasan psikis, kekerasan seksual, maupun kekerasan ekonomi. Dalam analisis yang telah dibahas diatas, maka konsep yang akan dibangun untuk mewujudkan perlindungan hukum terhadap korban tindak pidana perdagangan orang dalam sistem peradilan pidana adalah sebuah konsep yang dibentuk sebagai relasi interaksionis dan hirarkis antar sistem dalam kesatuan yang utuh dan menyeluruh (integral komprehensif). Yang oleh penulis diusulkan tentang "Konsep Perlindungan Hukum Integratif".

Dalam mewujudkan konsep perlindungan hukum integratif terhadap perlindungan korban tindak pidana 
perdagangan orang yang harus dibangun adalah interaksi antara sistem norma, sistem nilai, dan sistem perilaku dalam satu kesatuan. Dalam konsep tersebut harus dinyatakan secara jelas tentang pemenuhan hak-hak korban tindak pidana perdagangan orang, yang merupakan kata kunci keberhasilan memerankan fungsi hukum sebagai sarana pembaharuan masyarakat yang dilakukan dalam sistem yaitu sistem peradilan pidana.

\section{Hukum sebagai sistem norma.}

Dalam masyarakat yang paling sederhana sekalipun keberadaan norma hukum sebagai suatu pranata sosial secara nyata telah menjadi qonditio sine quanon bagi keberlangsungan masyarakat tersebut sebagai suatu entitas. Sebagaimana yang dinyatakan oleh Sudikno Mertokusumo, bahwa "hukum tidak dapat lepas dari kehidupan manusia, maka untuk membicarakan hukum kita tidak dapat lepas membicarakannya dari kehidupan manusia." 27 Norma hukum dalam peraturan perundang-undangan tentang perlindungan korban tindak pidana perdagangan orang haruslah stabil (stable), tetapi tidak boleh juga diam (still) atau kaku (rigid). Sepintas kelihatannya pernyataan tersebut saling bertentangan satu sama lain, tetapi sebenarnya tidak saling bertentangan. Karena, demikianlah salah satu "hakekat dari hukum di mana di satu pihak hukum harus mengandung unsur kepastian, dan prediktabilitas, sehingga dia harus stabil. Tetapi di lain pihak hukum haruslah dinamis, sehingga selalu dapat mengikuti dinamika perkembangan kehidupan manusia." ${ }^{28}$ Demikian juga dengan pembentukan peraturan perundang-undangan tentang perlindungan korban tindak pidana perdagangan orang haruslah mengikuti dinamika masyarakat sehingga dapat dicapai tujuan hukum berdasarkan nilai-nilai yang selalu hidup dalam masyarakat.

\section{Hukum sebagai sistem nilai}

Menurut Satjipto Rahardjo, "nilai merupakan salah satu paradigma hukum, sehingga nilai dapat dilihat sebagai sosok hukum juga." ${ }^{29}$ Peraturan perundang- undangan tentang perlindungan korban tindak pidana perdagangan orang sebagai salah satu hukum dalam masyarakat, merupakan suatu perwujudan nilai-nilai hukum yang mengandung arti bahwa, "kehadirannya hukum adalah untuk melindungi dan memajukan nilai-nilai yang dijunjung tinggi oleh masyarakat." ${ }^{30}$ Hukum yang dipandang sebagai suatu sistem nilai yang secara keseluruhan dipayungi oleh sebuah norma dasar (basic norm). Norma dasar inilah yang dipakai sebagai dasar dan sekaligus penuntun penegakan hukum. "Sebagai sistem nilai, norma dasar tersebut merupakan sumber nilai dan juga pembatas dalam penerapan hukum." 11

\section{Hukum sebagai sistem perilaku}

Dalam sistem perilaku (behaviour) hukum diharapkan mampu merekayasa atau merubah perilaku (engineering) masyarakat. Berdasarkan hal tersebut, "urgensi pembangunan hukum dalam rangka mewujudkan perlindungan korban dalam sistem peradilan pidana melibatkan tidak hanya pada pembangunan hukum substansial, tetapi juga pada struktural dan kultural." 32 Dalam perspektif ini tidak ada unsur power untuk menekan kehendaknya terhadap masyarakat, melainkan akan memberikan masukan bagi terbentuknya substansi hukum yang tidak mengajarkan apa yang ditetapkan hukum sebagai "apa yang seharusnya" tetapi diajarkan sebagai "apa yang sebenarnya." 33 Perspektif hukum yang demikian, yakni berusaha membenarkan atau mengakui "mitos keadilan" dalam norma perundangundangan untuk disesuaikan dengan rasa keadilan. Dengan kata lain menciptakan hukum yang lebih berkeadilan.

Maka setiap kali ada masalah perlindungan hukum terhadap korban perdagangan orang, hukumlah yang ditinjau dan diperbaiki, bukan manusia sebagai pelaku dan atau korban yang dipaksakan untuk dimasukkan ke dalam sistem hukum karena hukum bukan merupakan suatu institusi yang absolut dan final melainkan sangat bergantung pada bagaimana manusia melihat dan menggunakannya. Manusialah yang merupakan penentu sehingga hukum selalu berada dalam proses untuk terus menjadi lebih baik (law as a process, law in the making), artinya hukum yang harus ditinjau kembali dan hukum untuk manusia bukan sebaliknya, serta hukum dijalankan dengan hati nurani.

\section{SIMPULAN}

Perlindungan hukum terhadap korban tindak pidana perdagangan orang dalam hukum pidana di Indonesia dan Malaysia telah dilaksanakan namun masih banyak kelemahan-kelemahan. Untuk mengimplementasikan konsep yang ideal, maka pembangunan hukum harus sejalan dengan perkembangan masyarakat yang harus diciptakan melalui

\footnotetext{
${ }^{27}$ Sudikno Mertokusumo, Op. Cit., hal. 1.

${ }^{28}$ Munir Fuady, Teori-Teori Dalam Hukum, Kencana, Jakarta, 2013, hal. 1.

${ }^{29}$ Satjipto Rahardjo, Op. Cit., hal. 66.

${ }^{30}$ Ibid.

${ }^{31}$ Esmi Warasih, Pranata Hukum, Sebuah telaah Sosiologis, PT Suryandaru Utama, Semarang, 2005, hal. 80.

${ }^{32}$ Maya Indah, Perlindungan Korban: Suatu Perspektif Viktimologi dan Kriminologi, Edisi Kedua, Kencana, Jakarta, 2014,
} hal. 186.

${ }^{33}$ Ibid., hal. 187. 
pembentukan perundang-undangan (sistem norma) yang dinamis.

Dalam pembentukan hukum perlindungan korban kejahatan yang ideal dimasa yang akan datang, maka perlunya dilakukan pembaharuan hukum tentang perlindungan hukum terhadap korban tindak pidana perdagangan orang dengan mengharmonisasi peraturan- peraturan yang sudah ada dengan peraturan-peraturan lainnya baik peraturan internasional maupun nasional menjadi "Konsep Perlindungan Hukum Integratif". Yaitu sebuah konsep perlindungan hukum terhadap korban perdagangan orang dengan menguatkan interaksi antara aspek norma, aspek nilai dan aspek perilaku yang menyatu menjadi sebuah sistem hukum, yang meliputi sistem norma, sistem nilai dan sistem perilaku menjadi sistem perlindungan hukum integratif terhadap korban tindak pidana perdagangan orang dalam sistem peradilan pidana sebagai satu kesatuan yang utuh dan menyeluruh (Integral Komprehensif).

Konsep perlindungan hukum integratif diharapkan dapat dijadikan solusi untuk menyelesaikan permasalahanpermasalahan tentang perlindungan hukum korban tindak pidana perdagangan orang sesuai dengan jiwa bangsa Indonesia yang berdasarkan Pancasila dengan membuat harmonisasi peraturan-peraturan yang ada saat ini baik dari peraturan hukum internasional maupun hukum nasional.

\section{DAFTAR PUSTAKA}

\section{Buku}

Arif Gosita, 1987, Viktimologi dan KUHAP, Jakarta: Akademika Pressindo.

Dikdik M. Arief Mansur dan Elisatris Gultom, 2007, Urgensi Perlindungan Korban Kejahatan, Jakarta: Raja Grafindo Persada.

Esmi Warassih, 2005, Pranata Hukum, Sebuah telaah Sosiologis, Semarang, PT Suryandaru Utama.

Lilik Mulyadi, 2004, Kapita Selekta Hukum Pidana Kriminologi Dan Viktimologi, Jakarta: Djambatan.

Mardjono Reksodiputro, 1997, Bunga Rampai Permasalahan dalam Sistem Pidana, Buku II, Jakarta: Pusat Pelayanan Keadilan Dan Pengabdian Hukum Universitas Indonesia.

Maya Indah, 2014, Perlindungan Korban: Suatu Perspektif Viktimologi dan Kriminologi Edisi Kedua, Jakarta: Kencana.

Mohammad Shariff dan Aisyah, Undang-Undang Jenayah di Malaysia, Tanpa Tahun. Munir Fuady, 2013, Teori-Teori Dalam Hukum, Jakarta, Kencana.

Rusli Muhammad, 2010, Kemandirian Pengadilan Indonesia, Yogyakarta: FH UII Press. Satijipto Raharjo, 2000, Ilmu Hukum, Bandung, PT. Citra Aditya Bakti.

Sudikno Mertikusumo, 1999, Mengenal Hukum, Yogyakarta: Liberty.

Yesmil Anwar dan Adang, 2009, Sistem Peradilan Pidana: Konsep, Komponen \& Pelaksanaannya dalam Penegakan Hukum di Indonesia, Bandung: Widya Padjadjaran.

\section{Perundang-undangan}

Undang-Undang RI Nomor 21 tahun 2007 tentang Pemberantasan Tindak Pidana Perdagangan Orang

Undang-Undang RI Nomor 48 Tahun 2009 tentang Kekuasaan Kehakiman. Undang-Undang RI Nomor 31 tahun 2014 tentang Perlindungan Saksi dan Korban Undang-Undang RI Nomor 35 Tahun 2014 Tentang Perlindungan Anak

Akta 670 Malaysia tentang Anti pemerdagangan Orang dan Antipenyeludupan Migran 2007.

\section{Internet}

Rusliansyah,file:///F:/Traficking/Mengenal Sistem Kekuasaan Kehakiman di Malaysia.pdf, diunduh tanggal 1 November 2016. 